\title{
The Concept and Role of Money in Modern Economy: An Islamic Perspective
}

\author{
*Hafiz Moazzum Shah \\ ** Dr. Syed Abdul Ghaffar Bukhari
}

\section{ABSTRACT:}

Money has received a great deal of attention among Muslim jurists, because of its relevance to shariah issues such as zakat, usury, and sale, etc. These issues are definitely of great importance for all Muslims. This article proceeds with a discussion of classical concept of money as envisaged by early Muslim Jurists and their different point of views about the application of the term money. In second part, the concept and conditions of money according to modern Muslim Jurist and emergence of Islamic currency have been discussed. This part of the article also covers the comparative study of the role and functions of money in both conventional and Islamic economics system. The functions of money as discussed by the modern economists have been discussed by the early Muslim Jurists in detail. The last part of this study consists of the conclusion and findings of this article.

\section{Early Muslim Jurists and Money}

Keeping in view the evolution of money and many other historical considerations, we find that some Muslim jurists divided money into two kinds.

1. Natural Money or Real Money or Athman Mutlaqah

2. Constructive Money or Athman Muqayyadah

This classification is obvious from the texts of the different books of Muslim Jurists. For example, imam Zailaee syas:

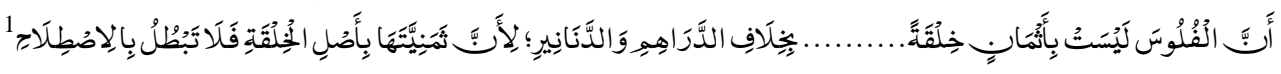

Contrary to the Gold and Silver coins, coper coins are not natural money because gold and silver coins are money by nature, so their status cannot be nullified by any type of agreement.

\section{Linguistic Meaning of Naqd (نقا):}

In Arabic literature the word Naqd (نق) is used for Money. Its plural is Nuqood نقود . It is used for different meanings. Literally, it means distinguishing or separation of fine coins of dirham from gold or silver coins mixed with inferior metals. This term is also used for spot payment and for gold and silver coins itself as well. ${ }^{2}$

We do not find the word (نقد) in the text of Quran or Hadith of the prophet SAW. The reason is that the people of Arabian Peninsula used the word "Dinar" for currency made up of gold and the word "Dirham" for the currency made up of Silver. Furthermore, the word Wariq was also used for silver currency and aeyen (العين) for gold currency. These terms have been used in the following verses of the holy Quran:

"Lecturer Department of shariah, Allama Iqbal Open University, Islamabad.

Email: smoazzum@gmail.com

${ }^{* *}$ Head Department of Islamic studies, National University of Modern Languages, Islamabad. 


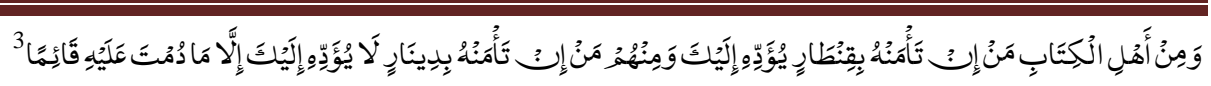

Among the people of book are some, who if entrusted with hoard of gold will pay it back and there are others who if entrusted with a single silver coin, will not repay it to you until you constantly stood demanding.

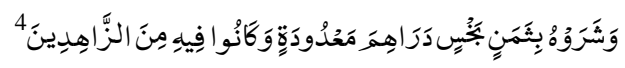

The (brothers) sold against a miserable price, for a few dirhams counted out in such low estimation did they hold him.

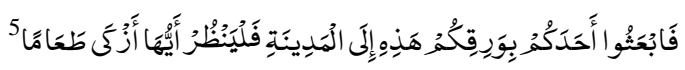

Now send one of you with this Wariq (Money) to the city and let him find out which is the best food.

The word Dirham, Dinar and Wariq have also been used in hadith.

The Muslim Jurists have used the same terminology in their books. They also use the word "Naqdian" (نقدين) and Athman (الأثمان) for gold and silver currency and "Fals" (فلس) for bronze coins. The famous Islamic Jurist Imam Shaibani says:

وإذا اشترى الرجل عشرة دراهم بدينار من رجل ونقده الدينار فله يكن عنده الدراهم فاستقرضها من الذي نقده الدينار وقبضها منه ثم.

$$
\text { دفعها إليه فإنه جائزة }
$$

If a person purchased from another ten Darahim against one dinar by spot-payment and paid one Dinar in cash and the seller did not have Darahim and took Darham as loan from the buyer and delivered the same to him after taking possession, the deal is permissible from shariah point of view.

\section{Terminological Meaning:}

What is Naqd (نقد)? After going through the classical literature on the term, we find three different points of views of the early Islamic Jurists.

1.According to some Hanafi and Maliki and majority of Shafi and Hanbali Jurists, the use of the term Naqd (نق) is not limited to the gold and silver minted coins rather the term is applied to all types and forms of gold and silver, whether minted or not. ${ }^{7}$

2. According to majority of Hanafi Jurists ${ }^{8}$ and some other jurists of Maliki ${ }^{9}$ and Shafi schools of thought ${ }^{10}$, the term Naqd (نقد) is applied only to the gold and silver minted coins. So the Bullions or raw gold is not Naqd (نقا). The Hanafi Jurists are of the view that thecapital of partnership and Mudaraba contract must be in monetary form. However, they do not allow raw gold or bullions as capital of partnership or Mudaraba contracts. It means that they do not apply the term Naqd (نقد) to the raw gold and gold bullions. Anyhow, both of these two opinions apply the term Naqd (نقد) only to the gold and silver, the natural money, and do not apply it to copper coins.

3. The third opinion is that, although the term Naqd (نق) is basically applied to gold and silver, however it can be applied to other things used as medium of exchange if certain conditions are fulfilled.

Of those who hold this opinion are the famous Muslim Jurists Muhammad Bin Al Hasan Al shaibani, ${ }^{11}$ some Maliki ${ }^{12}$ Jurists, Ibn Taimiyya ${ }^{13}$ and Ibnulqayyam ${ }^{14}$ of Hanbali school of thought. According to this point of view the term can be applied to bronze 
coins (fulus) as well because they call it thaman which also means a medium of exchange. These Muslim Jurists also apply all the rules of shariah related to money to the coins and currency made up of copper metals.

\section{Analysis of different Views:}

In general, we can say that there are two main schools of thought. One school of thought limits the application of the term money to gold and silver. The other school of thought do not restrict its application to gold and silver rather apply it to other mediums of exchange like fulus (bronze coins).

The reason for their different points of view about money is the customary practice. In the early Islamic era only gold and silver coins were mainly used as medium of exchange. Fulus, the bronze coins, were used as secondary medium of exchange in small financial transactions for cheap goods and services. Therefore, according to the early Islamic jurists, money is only gold and silver. They do not apply the shariah rulings related to money to mediums of exchange other than gold and silver.

However, with the passage of time, when the use of fulus (currency made up of bronze) became common and it was used in most transactions, the Islamic jurists considered them money and applied all the shariah rulings related to money to these Fulus.

Thus, thamaniyya, the Islamic terminology which means the ability to be used as medium of exchange, to a large extent is related to the customary practice. So anything that is used as medium of exchange can be called money if certain conditions are fulfilled that will be discussed later on. This application of the term money is supported by the views of famous Islamic jurist Al Imam Al Sarakhsi, who says:

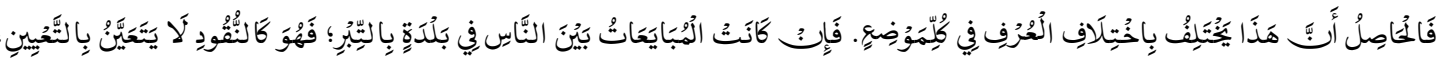

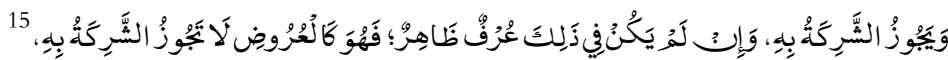

The application of the term money depends upon the customary practice and varies from place to place. If the general transactions that take place among the people are by the ingots or gold bullions than these ingots and bullions would be treated as money and can be used as capital of partnership contracts (a necessary condition, according to Hanafi point of view, for partnership contract is that its initial capital must be in monetary form). However, if there is no any customary practice than these ingots are considered as goods and not money, thus cannot become initial capital in the Musharaka contract. Another argument for the assertion that application of the term money is based upon customary practice can be quoted from Imam Malik, who says "if people started to use the currency made up of skins, I would dislike selling them against gold or silver with deferred payment ${ }^{16}$. We conclude from the foregoing discussion that there is a category of Muslim jurists who did not limit the application of "thamaniyya"to gold and silver in particular, rather expanded the concept of this term to include, in addition to gold and silver, everything that plays its role as a medium of exchange and thus apply the relevant shariah rulings to them accordingly.

\section{Definition of Money in Modern Islamic Economics:}

After the world has left the gold and silver standard and paper money, that has no 
intrinsic value, is introduced and because of unlimited number of things that perform the functions of money, it would be, to some extent, difficult to find an inclusive definition of money. However, the following definition by some Islamic Economists may be quoted. Money has been defined as: ${ }^{17}$ أي شيء يتمتع بقبول عامفي الوفاء بالإلتزمات

Anything that is generally accepted in fulfillment of obligations.

Definitely, here obligation means financial obligations. Another definition is:

$$
\text { كل شيء خال من الموانع الشرعية يتمحض للثمنية بكم، خلقته أو بكمم الإصطلاح العام لدى المتعاملين } 18
$$

Anything that is free from shariah impediments and specified to be used as medium of exchange by virtue of its creation or by the general convention of the people.

It means anything that is permissible from shariah point of view and is generally acceptable by everyone of the society in all types of transactions is called money, whether it has got this status by virtue of its creation like gold and silver or because people have agreed to use it as medium of exchange like fulus and paper currency.

This is a suitable definition of money that includes all types of money for the purpose of shariah rulings related to money. Anything that is called money according to this definition will be having characteristic of "thamaniyya", and the rulings related to Riba, Zakat and Sarf, that is exchange of currencies, will be applied.

However, this definition does not include some other instruments used as medium of exchange and called credit money like cheques and bills of exchange. Because, from shariah point of view credit money is not money itself, rather it is generally a promise to pay. So, they do not have thamaniyyah, hence, rulings related to Zakat, Riba and Sarf will not be applied.

Nevertheless, when measuring the total supply of money in the modern economy, the Islamic economists include credit money in the definition, because credit money plays its role in the economy like real money and reflects the economic activity. Therefore, for this purpose, the following generalized definition is better to include the credit money.

كلشيء خال من الموانع الشرعية يصطلح عليه الناس ليكوب توسيطالإستبدال ومقياسا للقيهة ويلتى قبولا عاما بين الناس 19

Anything that is free from shariah impediments used as medium of exchangeand measure of value and is generally accepted by the people.

So in this definition, credit money like cheques and bill of exchange are included. However, this definition is only to measure the supply of money in the economy. The shariah rulings related to money cannot be applied to cheques and bill of exchange because these instruments are not money in itself rather they are documents of promise to pay. Hence, it can be concluded from the above discussion that the nature and concept of money in Islam is just like its concept in economics, because the main point is general acceptance and medium of exchange.

\section{Evolution of Islamic Currency:}

To better understand the reasons and bases of the application of this term and to have a clear concept of the money in Islam; it is pertinent to mention here a short history of the evolution of Islamic coins. 
During the early era of Islam, the Arab did not have their specific money or any medium of exchange. Ahmad Ibn Yahyā al-Balādhurī, a 9th-century famous Muslim historian, has mentioned that the people of Arabian Peninsula used the Persian Darahim and Roman Dinar in the Pre-Islamic-era and during the era of Prophet the Muhammad PBUH. However, when the first Islamic state of Madina was established, the prophet S.A.W continued the use of Darahim and Dinar as a medium of exchange in day to day transactions which was issued by Byzantine and Sassanid Empire. ${ }^{20}$

Even though, some changes were adopted by the prophet Muhammad S.A.S that were already adopted by the people of Makkah. The people of Makkah used Darahim and Dananir as a medium of measurement by weight and not by counting due to possibility of fraud in the fineness and valuation of these Darahim and Dananir because it was foreign currency. So these coins were used like ingots or raw gold without considering them a minted currency. ${ }^{21}$ The prophet S.A.W ordered to use these Darahim and Dananir by weight. It is supported by a hadith narrated by Ibn e Umar:

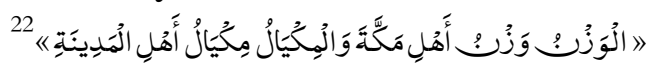

The weight (accepted) is the weight of people of Makkah and measurement (accepted) is the measurement of the people of Madina.

The Modern application of what we can understand from the change adopted by the prophet S.A.W, in the use of Darahim and Dananir, is that the material to be used for money or a medium of exchange was accepted however specific standards and descriptions were not accepted. In other words, gold and silver standards were accepted to be used as medium of exchange.

Another problem with these Darahim and Dananir was that they were of different shapes and weight. Therefore, for the purpose of shariah rulings related to Zakah and intrest, average weight of these Darahim and Dananir was adopted. The Persian Darahim were of different weights: some of them were 20 carats, some were of 12 carats and some others were of 10 carats. It was determined that dirham would be of 14 Qirat (carat) and the weight of this dirham was six Dawaniq. The Dirham was also equivalent to the weight of 25 wheat grains while ten darahim were equivalent to the weight of seven Mithqal of Gold. One Mithqal of Gold was equivalent to the weight of 72 wheat of grains. ${ }^{23}$

Thus, there was no Islamic currency minted by Muslims in the era of the Prophet. However, some measurements and weights were determined for the already available currency minted Byzantine and Sassanid Empire. After the death of prophet PBUH, the caliphs continued to use the same gold and silver coins. However, and despite their preoccupation with Islamic conquests, they thought about some changes in these coins. Hazrat Umar bin khattab, the second Caliph, ordered to add some Islamic inscriptions. The name of Hazrat Umar (R.A) was added to these coins. Hazrat Usman (R.A) during his era ordered to add the word "Allah Akbar" to them.

The printing of Islamic currency was important for an Islamic state. Even Hazrat Umar (R.A) is reported to have thought about making a currency of camel skins but 
he did not take steps to do so because he was told that the state may face lack of camels, a necessary means of transportation at that time. ${ }^{24}$

After the era of Rashidun Caliphates, during the early days of Omavid Caliphate the use of the same coins continued with the addition of Islamic scripts like Arabic words till the era of the fifth Omavid caliph, Abdulmalik Bin Marwan who reigned from the year $65 \mathrm{H}(685 \mathrm{AD})$ to $85 \mathrm{H}(705 \mathrm{AD})$ and his era of caliphate is known for development, prosperity and expansion of commercial activities.

Abdul Malik bin Marwan is the first caliph in Islamic history who formally minted gold and silver coins in 76AH called al-Dinar Al-Islami and Al-Dirham Al-Islami. Marwan also ordered the use of only one currency in the whole Islamic state. Before his era the currency was locally issued in different provinces of the Islamic state by some governors. He also restricted the process of minting coins to the central government. For this purpose, he assigned the task of minting currency to Hajjaj bin Yousuf, the governor of Iraq at that time. ${ }^{25}$

Islamic Dinar was equal to one Mithqal and was a bit lighter than the Roman Dinar which was 4.25 grams. The weight of Byzantine dinar was 4.55 grams. The weight of Dirham that was minted by Marwan was 6 Dawaniq. He also issued Fulus. After the monetary reforms and minting of Islamic money during the reign of the Umayyad Caliph Abdul-Malik, Islamic money remained free from any fraud like mixing of inferior metal, until the era of the Abbasid Caliph al-Mutawakkil. After his death, political situation got worse. Due to political unrest some governors of the Islamic state started to issue currencies and would mix inferior metals in the gold and silver coins to meet the needs of public finances. These mixed coins were better to meet expenses because their face value which was fixed by the government authorities was higher than the real value. Due to this mixing of inferior metals with gold and silver coins and absence of central currency issuing authority, different types of Darahim were introduced in the market. They were called al-Darahim al maghshusha (coins mixed with inferior metals). As per quality of their fineness they were given different names like Darahim zuyuf, Darahim naqira, Darahim bahraja etc ${ }^{26}$

Although some currencies made up of other metals like bronze were also used in cheaper transactions, the gold dinar and silver dirham remained the dominant currency throughout the Muslim history until the era of Ottoman caliphate. The use of these gold dinar and silver dirham continued in Ottoman caliphate. However, when the Othmani caliphate collapsed in 1942, the gold dinar and silver dirham vanished and it had marked an end of them in classical Islamic world and financial system. Thus Islamic currency was in 3 denominations: 1. Dinar (gold coins), 2. Dirham (Silver Coin), 3. Fals (bronze Coins) Bronze coins were used as medium of exchange for cheaper goods and services. ${ }^{27}$

\section{Conditions for money in Islam: Gold and silver:}

As discussed previously, some jurists apply the term Naqd (نقا) only to the gold and silver, the natural money, and do not apply it to copper coins. According to these jurists' money must be in the form of gold or silver. The condition of minting as expressed by some other jurists is not effective in riba and obligation of zakat. Those 
who stipulate that money or Naqd must be in minted form are of the view that Riba and Zakat are obligatory in bullions of gold because of characteristic of thamaniyya that is found in them by virtue of creation.

\section{Riwaj (circulation)}

The second condition for money in shariah as determined by the Islamic jurists is that it must be in Riwaj. Literal meaning of Riwaj is circulation. However, in Islamic Fiqh the term Riwaj has specific meaning.

According to Jurists, the term Riwaj includes the meaning of circulation which means that the currency must be generally used as medium of exchange. Circulation is necessary condition for money to apply relevant shariah rulings on it. Riwaj also means that people must have an interest in it as it must be an attractive wealth for them. It must be a dominant currency so that when any financial transaction is concluded it must be understood that the medium of payment would be in that currency even if it is not expressed in the contract agreement. The famous Islamic Jurist Ibnulhummam says:

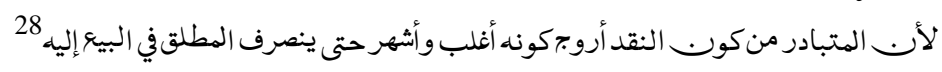

Because what comes to our mind immediately from the condition, that money must be generally used as medium of exchange, is that it must be a famous and dominant currency so that in an absolute sell agreement this currency would be considered as medium of exchange. Furthermore, this condition is for currency made up of anything other than gold and silver because gold and silver are thaman (medium of exchange) by virtue of their creation even if they are not in circulation. However, in some contracts like Mudaraba or Musharaka some Islamic Jurists put a condition that the initial capital of these contracts must be in cash form. But not accepting gold bullions as initial capital of these contracts does not mean that gold bullions are not thaman (medium of exchange). There is a bit difference between thamaniyyah and Naqdiyya. What can be understood form the expressions of Jurists are that thaman means medium of exchange while Naqd (نقد) means medium of exchange in a most liquid form. Thus Gold bullions are thaman but they are not Naqd (نقد) because they are not in cash form.

\section{The Functions of Money:}

in conventional economics the concept of functions of money is that it is used as Medium of Exchange, Unit of Account, Store of Value, Standard of deferred payment.

We have mentioned the functions of money according to economists, but did our jurists know these functions and did they talk about them?

After going through the writings of Muslim jurists about money we find that they have discussed the functions of money under the topics of Zakat, interest and other relevant topics. The famous Islamic Jurist Ibn ul Arabi says:

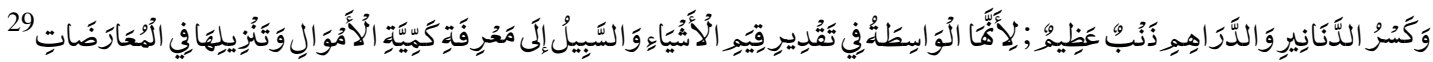

Ibn ul Hummam, a famous Hanafi Jurist says:

وقولهه في النقدين خلقا للتجارة معناه أفما خلقا للتوسل بهما إلى تحصيل غيرهما.............. فخلق النقداب لغرض أن يستبدل بهما ما

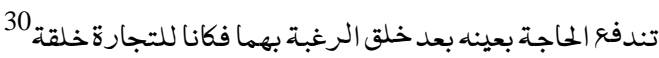


Imam Malik says: ${ }^{31}{ }^{31}$

Ib ne Rushd says:

$$
\text { وأما الدينار والدرهم فعلة الهنء فيها أظهر إذكانت هذه ليس المقصود منها الربح وإنما المقصود بها تقديرالأشياء التي لها منافي ضرورية. } 32
$$

Ibn ul Qayyam says that Darahim and Dananir are mediums of exchange. Medium of exchange is something that is used as measurement of value to know value of different things ${ }^{33}$. Furthermore, Allama Ibn e Taimiyya sys that Darahim and Dananir are mediums of exchange, and they are used as standard of value for mutual transactions, and they are not sought for themselves. ${ }^{34}$

The above mentioned writings of the Islamic Jurists reveal that Islamic jurists have almost mentioned the same functions of money as mentioned by the economists.

It is obvious from the above writings of the famous Muslim Jurists that money is used as medium of exchange, unit of account and measurement of value. As for as the function of money as store of value is concerned, some modern Islamic economists do not accept this function of money arguing that accepting this function of money means to allow money storage that will open the door for Riba. Furthermore, storage of money is against its function as medium of exchange because if it is stored, it will disturb its normal required circulation; hence disturb its role as medium of exchange. ${ }^{35}$

However, this point of view ignores the reality that function of money as store of value is the result of its role as medium of exchange, as anything that plays its role as medium of exchange must have the ability to store the value. If it does not store the value, how will people keep it with them for use in near future?

Therefore, Ibn e khaldoon, an Islamic jurist and historian says:

$$
\text { ثمّ إِّ الله تعالى خلق الحجرين المعدنيّين من الذّهب والفضّة قيمة لكلّ متموّل، وهما الذّخيرة والقنية لأهل العالم في الغالب } 36
$$

So all these functions that are mentioned by the economists have already been discussed by the Islamic Jurists, thus acceptable by shariah.

\section{Conclusion}

1. In Arabic literature the word Naqd (نقد) is used for Money. However, we do not find the word (نقا) in the text of Quran or Hadith of the prophet SAW. The reason is that the people of Arabian Peninsula used the word "Dinar" for currency made up of gold and the word "Dirham" for the currency made up of Silver. Furthermore, the word Wariq was also used for silver currency and aeyen (العين) for gold currency.

2. There are two main schools of thought. One school of thought limits the application of the term money to gold and silver. The other school of thought do not restrict its application to gold and silver rather apply it to other mediums of exchange like fulus (bronze coins). The reason for their different points of view about money is the customary practice.

3. There was no Islamic currency minted by Muslims in the era of the Prophet. However, some measurements and weights were determined for the already available currency minted by Byzantine and Sassanid Empire.

4. Abdul Malik bin Marwan is the first caliph in Islamic history who formally minted 
gold and silver coins in 76AH called al-Dinar Al Islami and Al-Dirham Al-Islami. Islamic Dinar was equal to one Mithqal and was a bit lighter than the Roman Dinar which was 4.25 grams. The weight of Byzantine dinar was 4.55 grams. The weight of Dirham that was minted by Marwan was 6 Dawaniq. He also issued Fulus.

5. The necessary condition for money in Islam is Riwaj which means that the money must be in Circulation and generally accepted to apply relevant shariah rulings on it. people must have an interest in it and it must be an attractive wealth for them.

6. The early Muslim Jurists have almost mentioned the same role and functions of money as mentioned by the conventional economists.

\section{References:}

${ }^{1} \mathrm{Al}$ zailaee, usman bin Ali, (743 AH), tabyeenulaHaqaieqsharahkanzuddaqaieq, almatbaahalkubraalamiriyyah, Cairo, vol: 94P: 90

${ }^{2}$ Alfairoz Abadi, AlqamoosAlmuheet, under the word "قنق "-IbneManzoor, Lisaanularab, under the word, “ق “" “ق "

${ }^{3}$ Surah, Alimran:75

${ }^{4}$ Surah Yousuf: 20

${ }^{5}$ Surah alkahf: 19

${ }^{6} \mathrm{Al}$ shaibani, Muhammad bin Hasan, AlAsl, Beirut, labanan, First edition, 1433 AH, 2012, v: 2, P: 603

${ }^{7}$ Usamn Bin Ali Al zailaei, tbyynāḷ̣qāiqsharḥkanzāldqāiqwḥāšy, Al matbaahalkubraBolaq Egypt, $1^{\text {st }}$

Edition, 1313 AH, vol: 1, P: 88-----

IbnulHummam, Muhammad bin abdulwahid, (861), FathulQadeer, DarulFikr, Vol: 7, P: 16

$$
\text { فتح القدير= كما في إناءين من جنس واحدحديد أو ذهب أو فضة أحدهما أكثروزنا من الآخر ففي الإنائين من غير النقدين إيجوز بيع أحدهما بالآخر }
$$

Al Haithami, Ahamd bin Muhammad bin Ali, tuhfatulMuhtaj Fi SharhiMinhaj, 1983-1357, V:4, P:279

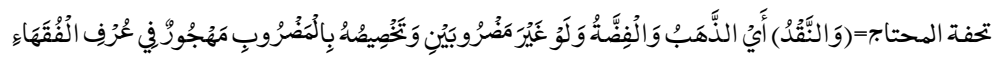

Al khirshi, Muhammad bin Abdullah (1101), sharahMukhtasar Khalil Lil KhirshidrulFiklilTabaah,

Beruit, Vol: 5, P: 262

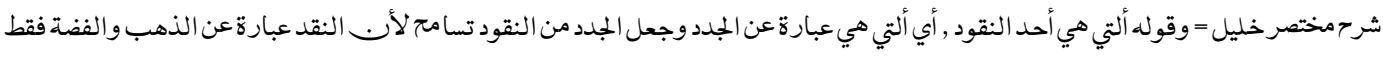

Al Sharbini, Muhammad Bin Ahmad Al khateeb, (977), MughnilMuhtaj Ila Maarifati Al fazilMinhaj,

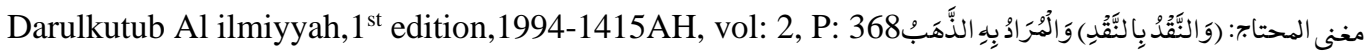

${ }^{8}$ Al Sarakhsi, Muhammad Bin Ahamad, (483AH), Al Mabsoot, DarulMaarifa, Beruit, Vol:11 P: 159

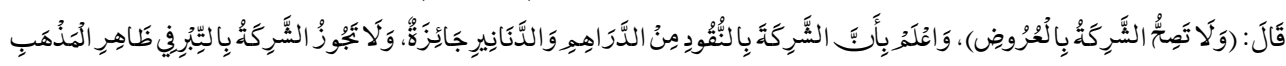

${ }^{9}$ Alesh, Muhammad Bin Ahamad, MinhuljalilsharahMukhtasar Khalil, DarulfikrBeirut, 1409, v4, P493

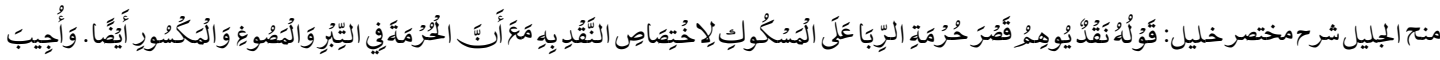

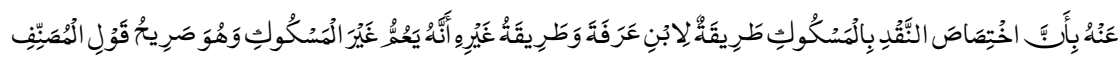

${ }^{10} \mathrm{Al}$ Bujairami, al tajreedlinafhilabeed (HashiyatulBujairami), Matbaah Al Halbi, 1369AH, v: 3, P:146

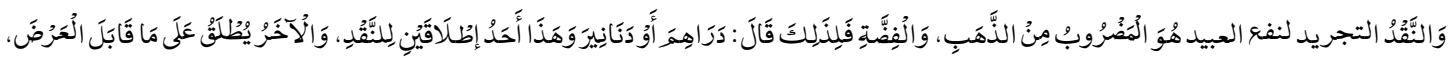

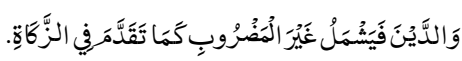

${ }^{11}$ Al shaibani, Muhammad bin Hasan, AlAsl, Idratul Quran WalUloom Al Islamiyyah, vol, 05, P: $57-$ Al Alkāsān̄i, 'lāūddīn, abūbakar bin masūdalḥanafī, (587), badā' 'ūssāna' 'Dārūlkūtūb al 'lmiyyah, Second Edition,1406 AH, Vol: 6, P: 59

${ }^{12}$ Mālīkbīnanās, al MŪḌāwWānā, alkūbrā, (179AH), dārūlkūtūbalilmīyyā, Beruit, Labnan, V: 3 , P: 5

${ }^{13}$ Ibnetaymiyyaah, Ahmad Bin Abdul Haleem (728AH), MajmuulFatawa, Majmaul Malik Fah, Saudia 
Arabia,-1995 1416 Ah, Vol: 29, P: 469

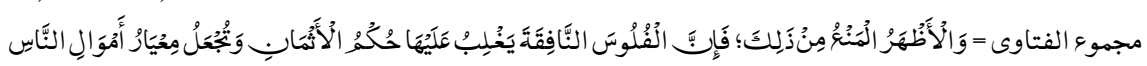

${ }^{14}$ IbnulQayyimAljoziyyah, Muhammad Bin Abi Bakar, iHlamulmooqieen an RabbilAAlamin,

Darulkutub al ilmiyyahBeruit, 1991-1411Ah, VOl:2 P: 105

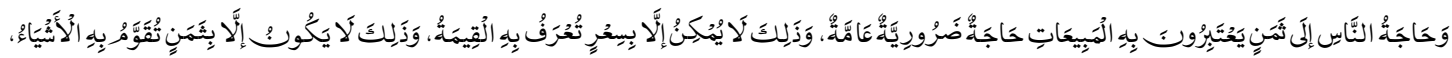

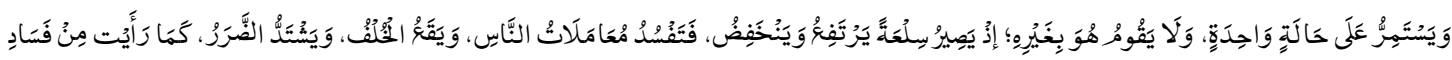

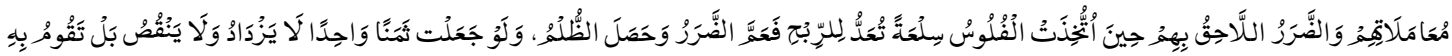

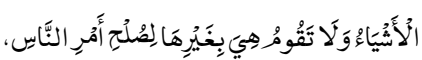

${ }^{15}$ Al Sarakhsi, Muhammad bin Ahamd, Al-Mabsoot, darulMaarifa, Beruit, 1414AH, vol: 11, P:1160

${ }^{16}$ Mālīkbīnanās, al MŪḌāwWānā, alkūbrā, (179AH), dārūlkūtūbalilmīyyā, Beruit, Labnan, Vol: 3, P:5

${ }^{17}$ Shaafi, Muhammad zakki, Muhqaddima fi al-NuqoodwalBunook, DarulNahza Al Arabia, 1982,32

${ }^{18}$ Musa aadamEisa, Al-tawazun al-NaqdiwalHaqiqi Fil Iqtisad Al-Islami, PHD thsis, 1410-1990, in

Islamic economics, UmmulQuraUniveristy, P: 185

${ }^{19}$ Ibid: P: 188

${ }^{20} \mathrm{Ibn}$ e Khaloon, Abdurrehman Bin Muhammad, TariekhIb e Khaldoon, DarulFikr, Beruit, second Edition, 1480Ah-1988, Vol: 1, P: 323

${ }^{21}$ Al Bilaziri, Ahmad ibn Yahyā, FutoohulBuldan, Dar waMaktabahtHilal, Beruit,1988, P: 488

22 Abu dawood, Sulaiman bin Ashath Al Sajistani, Sunan Abi Dawood, DarulKitab Al Arabi, Beruit, vol: 3, P: 251, Hadith no: 3342

${ }^{23}$ SalmyEdawatiYaacob and others, Gold Dinar as A Supreme Currency: Review Based On the History of Islamic Civilisation, Advances in Natural and Applied Sciences, 6(3): 348-356, 2012 ISSN 1995-

0772, P: 350

${ }^{24} \mathrm{Al}$ Muqraizi, abdulqadir, shauzurulauqood Fi zikri al Nuqood, P: 3,4

${ }^{25}$ Ibid: P: 10

${ }^{26}$ AhamadHassan, Tatawwur al Nuqood Fi zau Al shariah Al islamiyyah, PHD thesis, alfiqhwausulihi, Islamic economics Ummuqurah university, P: 82

${ }^{27}$ SalmyEdawatiYaacob and others, Gold Dinar as A Supreme Currency: Review Based On the History of Islamic Civilisation, Advances in Natural and Applied Sciences, 6(3): 348-356, 2012 ISSN 19950772, P: 352

${ }^{28}$ IbnulHummam, Muhammad bin abdulwahid, (861), FathulQadeer, DarulFikr, Vol: 2, P: 220

${ }^{29}$ IbnulArabi, Muhammad bin Abdullah, AhkamulQuraan, Darulkutub Al ilmiyyah, Vol: 5, P: 29

${ }^{30}$ IbnulHummam, Muhammad bin abdulwahid, (861), FathulQadeer, DarulFikr, Vol: 2, P: 155

${ }^{31}$ Malik bin Anas, almudawwanah, Darulkutu al Ilmiyyah, first Edition,1415AH-1994, Vol: 4, P: 527

${ }^{32}$ IbneRushd al hafeed, Muhammad bin Ahmad (595AH), Bidayatul Mujtahid, WaNihayatulMuqtasid, Maktba ah Mustafa, Egypt, $4^{\text {th }}$ Edition, 1395Ah-1975, vol:2

${ }^{33}$ IbnulQayyimAljoziyyah, Muhammad Bin Abi Bakar, iHlamulmooqieen an RabbilAAlamin,

Darulkutub al ilmiyyahBeruit, 1991-1411Ah, VOl:2 P: 105

${ }^{34}$ Ibnetaymiyyaah, Ahmad Bin Abdul Haleem (728AH), MajmuulFatawa, Majmaul Malik Fah, Saudia Arabia,-1995 1416 Ah, Vol: 29, P: 469

${ }_{35}$ Abu Saud, Mahmood, KhutootRaiesiyyah Fil IqtisadAlislami, Maktaba Al Manar Al islamiyya, Kuwait, $3^{\text {rd }}$ edition, 1388AH-1968, P: 27,28

${ }^{36}$ Ibn e Khaloon, Abdurrehman Bin Muhammad, TariekhIbneKhaldoon, DarulFikr, Beruit, second Edition, 1480Ah-1988, Vol: 1, P: 323

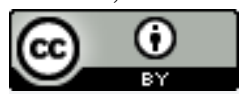

This work is licensed under a Creative Commons Attribution 4.0 International License. 